Yayın Gelis Tarihi: $\quad 09.05 .2016$

Yayın Kabul Tarihi: 12.10.2016

Online Yayın Tarihi: 13.07.2017
Dokuz Eylül Üniversitesi İktisadi ve İdari Bilimler Fakültesi Dergisi

Cilt:32, Sayl:1, Yll:2017, ss. 167-200

\title{
Psikolojik Sahiplenme: Örgütsel Alana İlişkin Bir Model Önerisi
}

\author{
Zeki UÇAR ${ }^{1}$
}

\begin{abstract}
$\ddot{\boldsymbol{O}} \boldsymbol{z}$
Günümüzde artan sayıda araştırma işgörenlerin örgütlerini ve işlerini psikolojik olarak sahiplenmelerinin, olumlu örgütsel çıtılar üzerindeki etkilerini ortaya koymaktadır. Ancak psikolojik sahiplenme olgusunun tam olarak ne olduğu, örgütsel alanda nasil geliştĭgi, hangi formlarda ortaya çıktığ ve örgütsel çıktılarının ne olduğu konusunda araştırmaların yeterli olgunluğa erişmediği araştırmactlar tarafindan siklikla dile getirilmektedir. PS (Psikolojik Sahiplenme) olgusunun teorileşmesi yönündeki eksikliğe bağll olarak bu çalışmada PS olgusunun örgütsel alan içerisinde teorileşmesine katkı sağllanması amaçlamaktadır. Özgün bir model üzerinden tasarımlanan çallşmada model üzerindeki değişkenler arasındaki ilişkiler kuramsal analizlere bağlı olarak ele alınmıştır. Araştırma sonucuna bağll olarak olgunun kavramsallaşmasl, örgütsel alan içerisinde ne şekilde geliştiği ve örgütsel alana iliş̧kin çıktıları üzerinde sağlam bir teorinin oluştuğu söylemek zordur. PS olgusunu örgütsel alan içerisinde bütüncül bir bakıș açısıyla ele alan bu çalışma olgunun teorileşmesine ilişkin yapılacak ampirik çalışmalara kuramsal bir altyapı hazırladı̆̆ için önemlidir.
\end{abstract}

Anahtar Kelimeler: Psikolojik Sahiplenme, Örgütsel Ortam, İsgören Tutum ve Davranışları.

Jel Sintflandirma Kodlart: L29, M12.

Psychological Ownership: A Model Proposal For Organizatıonal Area

\begin{abstract}
Nowadays, an increasing number of research reveals that employees' sense of ownership to their own work and organization has positive outcomes on organizational outcomes. But, the issues of what psychological ownership (PO) phenomenon exactly means, in which forms it emerges, how it develops in the organizational field and what their organizational outputs are, have not been investigated in depth. Given the lack of conceptualization of $P O$ in the literature, this study aims to contribute to the theory building process of $P O$ in the field of organization. By introducing th enique model in this paper, therelation ship among variables were examined based on the theoretical analysis. The current review states that it is difficult to claim that a robust theory and framework has been developed in conceptualizing PO construct and its outcomes in the existing literature. This study is important because it adopts a holistic view on PO by providing a solid foundation on the topic to contribute to its theorization and calls for an emprical research in thefuture.
\end{abstract}

Keywords: Psychological Ownership, Organizational Environment, Employee Attitudes and Behaviors.

Jel Classificaton Codes: L29, M12.

${ }^{1}$ Araş. Gör. Dr., Bitlis Eren Üniversitesi, İktisadi ve İdari Bilimler Fakültesi, İşletme Bölümü, Yönetim ve Organizasyon Anabilim Dalı, zeki.ucr@gmail.com. 


\section{GİRIŞ}

\section{Z.UÇAR}

İnsanoğlu, dünyadaki varlığıyla birlikte somut birçok nesneye sahip olmuş ve sahip olmanın toplumsal ve/veya yasal konumuna bağlı olarak bir takım haklar elde etmiştir. Temel olarak bireye nesneyi kontrol etme ve düzenleme yetkisi veren bu haklar, bireyin hedef nesneye karşı sahiplenme hissi geliştirmesini sağlamaktadır. Ancak bireyler, maddi sahipliğin yanı s1ra (Asatryan ve Haemoon Oh, 2008: 363), maddi olmayan (soyut) olgulara da psikolojik temelde güçlü hisler geliştirmektedir. Bu durum sahipliğin duygusal bağlamına vurgu yapmaktadır. Nitekim, sahiplik duygusunun önemli psikolojik ve davranışsal etkilere sahip olduğunu belirten İsaacs (1933), daha çocukluk döneminden başlanarak sahiplik hissinin insanoğlunda gözlemlendiğini belirtmektedir (Pierce vd., 2001). Dolayısıyla bir nesneye sahip olma isteği, insan doğası ile de açıklanabilir. Etzioni (1991) ve Pierce vd.'nin (1991) sahipliği iki farklı düzeyde ele aldıkları görülmektedir. Bunlar yasal düzeyde sahiplik ve psikolojik düzeydeki sahiplenme ile ilgilidir. Yasal sahiplik, sahipliğin bilişsel yönünü temsil ederken, psikolojik sahiplenme ise duygusal yönünü temsil etmektedir. $\mathrm{Bu}$ iki düzey birbirinden bağımsız olarak görülse de (Etzioni, 1991) bilişsel temeldeki sahiplik olgusunun (Pierce vd., 2003: 86; Asatryan ve Haemoon Oh, 2008: 363; Avey vd., 2009: 174) sahiplik psikolojisini harekete geçirdiği söylenebilir. Sahipliğin duygusal yönünü oluşturan bu durum, kişinin obje ile olan ilişkisinin de devamını sağlamaktadır (Asatryan ve Haemoon Oh, 2008: 363).

Örgütsel bağlamda finansal sahiplik olgusunu ele alan araştırmalarının yapıldığı bilinmektedir (Florkowsky, 1987; Buchko 1992). Özü işgörenin çalıştığı işyerine ortak yapılması planına (Employee Stock Ownership PlanESOP) dayanan bu araştırmalarda, işgörenlerin moral, motivasyon ve performanslarını arttırılması amaçlanmıştır (Vandewalle vd., 1996:210). 
Ancak araştırma sonuçları, işgören olumlu tutum, davranış ve performansına ilişkin çelişkili sonuçlar ortaya koymuştur (Pierce ve Furo: 1991). Elde edilen bu çelişkili sonuçların nedenini araştıran Pierce ve Furo (1991), finansal sahipliğin her koşulda olumlu işgören tutum ve davranışı ortaya çıkartmayacağı sonucuna ulaşmıştır. Pierce ve Furo (1991)'ya göre, işgörenlerin duygusal düzeyde sahiplenme hissetmeleri için yasal sahipliğin haklarından da yararlanmaları gerekmektedir. Bu bağlamda yasal sahiplik yazınını inceleyen Pierce vd. (1991) ilgili yazının yasal sahipliği genel olarak üç temel hak üzerinden tanımlandığını belirtmektedirler. Bu haklar 1) nesnenin fiziksel ve/veya finansal değeri üzerinde bir kısım hisselere sahip olma hakk1, 2) sahip olunan nesne üzerindeki kullanma (kontrol) hakkı, 3) sahip olunan nesne hakkında bilgi alma hakkı olarak tanımlanmaktadır (Pierce vd., 1991: 125). Bu haklar üzerinden Psikolojik Sahiplenme (Psychological Ownership-PO) kavramını ortaya koyan Pierce vd. (1991), yasal sahiplik durumu olmadan da işgörenlerin işlerine ve örgütlerine karşı sahiplenme hissi geliştirebileceklerini iddia etmişlerdir. Nitekim bir çok araştırma bu savı destekler niteliktedir (örn., Pierce, Kostova ve Dirks, 2001; Dirks,2003; Pierce vd., 2004; Pierce ve Rodgers, 2004; Van Dyne ve Pierce, 2004; Mayhew vd., 2007).

Pisikolojik Sahiplenme (PS) olgusunun örgütsel davranış araştırmaları için uygun bir yapıya sahip olması, alan yazında konunun ilgi görmesini sağlamıştır. Gerçekleştirilen ampirik çalışmaların pozitif örgütsel davranış alanına yoğunlaştığını belirten Avey vd. (2009: 174), halen teori geliştirme ve ampirik çalışmalara ihtiyaç olduğunu belirtmektedir. Bu çalışmada, PS olgusunun örgüt koşulları içerisinde hangi dinamiklerin etkisinde ne şekilde ortaya çıktığının kapsamlı bir model üzerinden tartışılması ve ilişkiler ağının ortaya konması amaçlanmıştır. Bu çalışmaya özgün geliştirilen model içerisindeki ilişkiler seti, sonraki ampirik araştırmalar için kuramsal katkı 


\section{Z.UÇAR}

sağlayacak yapıda olması açısından önemlidir. Bu yönüyle bu çalışmanın PS olgusunun teorik altyapısının güçlenmesi bakımından katkı yapacağ 1 düşünülmektedir. Ayrıca Türkiye' de PS ile ilgili araştırmaların neredeyse yok denebilecek kadar az oluşu da dikkat çekicidir. Bu yünüyle olgunun Türk Yönetim ve Organizasyon yazınına kazandırılarak alandaki araştırmaların zenginleşmesi bakımından da önem arz etmektedir.

\section{LITERÜTÜR İNCELEMESİ}

Etzioni'nin (1991) sahipliği sembolik ve bağlamsal olarak iki düzeyde ele aldığı görülmektedir. Etzioni’ye (1991: 465) göre bu düzeyler insan zihninde var oldukları sürece farklı bir psikolojik deneyim düzeyi de ortaya çıkacaktır. Yine Etzioni’nin (1991)' çalışmasıyla aynı döneme rastlayan Pierce vd.'nin de (1991) benzer bir tespit yaptıkları görülmektedir. Pierce vd. (1991: 124) göre sahiplik, kendi doğasında çok boyutlu bir yapıya sahiptir. Bu boyutlar yasal (formal, objective) sahiplik olgusu ve psikolojik olarak deneyimlenen sahiplik olgularıdır. Ancak Pierce vd. (2003: 5-6), bu düzeyleri ilişkili görmesine rağmen, yasal (finansal) sahiplik ve psikolojik sahiplenme arasında önemli farklılıkların olduğunu belirtmektedirler. Araştırmacılar göre yasal sahiplik kamusal bağlamda yasal dayanaklara sahipken, psikolojik sahiplenme ise kişisel bağlamda sahip olunan hislere dayanmaktadır. Psikolojik ve sosyolojik bağlam içerisindeki çalışmaları ve sosyal uygulamaları incelediklerini belirten Pierce vd. (2001: 299), Pierce vd. (2003: 5) sahiplik duygusuna ilişkin üç önemli tespit yapmaktadırlar. İlk tespit, sahiplik duygusunun insani bir durum olduğudur. İkinci tespit, insanların doğadaki maddi ve maddi olmayan çeşitli tüm objelere yönelik hisler geliştirdikleridir. Son tespit ise, sahiplik duygusunun önemli davranışsal, duygusal ve psikolojik sonuçlarının olduğudur (Pierce vd., 2003: 1). 
CatherineWebb,(1912) işgörenlerin çalışmış oldukları işyerlerine ortak yapılarak daha gayretli, hevesli ve dikkatli çalışmalarına ilişkin güdülerinin harekete geçirebileceğini iddia etmiştir. Bu çalışmayla birlikte, sonucu iş görenlerin çalışmış oldukları işyerlerinin hisselerine sahip olma planı (ESOP ) ve oradan da psikolojik sahiplenmeye uzanan bir yazın dizininin başladığı görülmektedir.

Örgütsel bağlamda sahipliğe ilişkin ilk araştırmaların finansal sahiplik bağlamında geliştiği görülmektedir (örn; Florkowsky, 1987; Buchko 1992). Bununla birlikte örgütsel alana ilişkin sahiplik araştırmalarını 1970 öncesi dönem, 19970-1990 arası dönem ve 1990 sonrası dönem olmak üzere üç kısımda ele almak mümkündür. Bütünüyle iş görenlerin finansal sahiplikleri ekseninde örüntülenen 1970 öncesi araştırmalar, iş gören devir hızı, devamsızlık, şikâyetleri azaltma (U.S. News and World Report, 1976), iş gören yabancılaşması, örgütsel etkililik (Derrick ve Phipps, 1969) gibi işyerlerinde var olan temel problemlerin çözümüne odaklandığ 1 görülmektedir. Finansal sahipliğin çalışanlar üzerinde psikolojik farklılaşma yaratmas1 sayesinde (Vandewalle vd.,1996:210) bu problemlerin aşılabileceği belirtilmektedir (Pierce vd., 1991: 121). Örneğin Florkowsky(1987: 622), kar bölüşümün firma üretkenliği ve ürün veya hizmet kalitesini pozitif yönde etkilediğini ve personel devir hızı ve iş gören devamsızlığı üzerinde negatif bir etkiye sahip olduğunu belirtmektedir. Sonuç olarak öncü çalışmaların işgörenlerin çalışmış oldukları iş yerlerine ortak olmalarını esas alan ve bu temelde işgörenlerin davranışları ve performansları üzerindeki değişiklikleri konu edinen bir yapıda geliştiği söylenebilir.

1970 sonrası dönemde ise kavramsal ve ampirik çalışmaların eksenine olumlu işgören tutum ve davranışlarının yerleştiği belirtilmektedir ( Pierce vd. 1991; Pierce ve Furo, 1991). Dolayısıyla finansal sahiplik çalışmalarının 
$\begin{array}{ccccc}\text { Z.UÇAR } & & \\ \text { psikolojik çıtılara yöneldiği } & \text { anlaşılmaktadır. } B u \text { dönem içerisinde }\end{array}$ gerçekleştirilen çalışmaları ele alan Pierce vd. (1991) literatürdeki çalışmaların dağınık bir görüntü sergilediğini bildirirken; işgören sahipliğinin iş gören tutum ve davranışı üzerine etkisini süreçleyen iyi ve gelişmiş kavramsal ve teorik alt yapının gerekli olduğunu belirtmektedirler (Pierce vd., 1991: 122). Bu bağlamda Pierce vd. (1991) İşgörenlerin Çalıştıkları İşyerlerinin Hisselerine Sahip Olma Projesi temelinde yapılandırmış oldukları çalışmada; sahipliğin üretebileceği sosyo-psikolojik ve davranışsal etkilerin oluşturduğu koşulsal düzeni açıklamak için ilişkiler ağını ortaya koyan bir model geliştirmişlerdir. Her ne kadar finansal bir zeminden hareket etse de araştırmacıların ortaya koymuş oldukları ilişkiler seti, yasal sahipliğin bireye sağlamış olduğu temel haklar üzerinden psikolojik sahipliğe neden olduğu tezine destek sağlamaktadır.

Bir diğer araştırmada Pierce ve Furo'nun (1991) finansal sahiplik ile işgören tutum ve davranışları arasındaki ilişkileri konu alan araştırmaları inceledikleri anlaşılmaktadır. Araştırmacılar, işgörenlerin çalışmış oldukları işyeri hisselerine sahip yapılma planlarının, işgörenlerin olumlu tutum ve performansları üzerinde değişik sonuçlar ortaya çıkardığını fark etmişlerdir. Araştırmacılar için bu durum teoride bir eksiklik olduğuna ya da finansal sahiplik planlarının iyi kurgulanmadığına işaret etmekteydi. Sorunun neden kaynaklandığını anlama çabası içerisine giren Pierce ve Furo (1991), resmi sahiplik planlarının hangi koşullarda olumlu tutum ve davranışsal çıktılar üretebileceği sorusuna yanıt aramışlardır. Araştırma, yasal sahiplikle eşdeğer olarak görülen finansal sahipliğin, yasal sahipliğin içermiş olduğu hakları bireye tanımadığında, sahipliğin duygusal düzeye ulaşamayacağını ortaya koymuştur. Dolayısıyla ESOP'a ilişkin araştırmaların neden farklı sonuçlar ürettiği ortaya çıkmıştır. Bu planlar ile işgören, sadece kara ortak yapılmaktaydı. Oysaki Pierce vd.'nin de (1991) belirtmiş oldukları gibi 
sahipliğin temelinde bir takım haklar yatmaktadır. Nitekim, sahipliğin çok boyutlu bir yapıyı içerisinde barındırdığını belirten Pierce vd. (1991) yazının yasal sahipliği genel olarak üç temel hak üzerinden tanımladığını belirtmektedirler. Bu haklar 1) nesnenin fiziksel ve/veya finansal değeri üzerinde bir kısım hisselere sahip olma hakk1, 2) sahip olunan nesne üzerindeki kullanma (kontrol) hakk1, 3) sahip olunan nesne hakkında bilgi alma hakkı olarak tanımlanmaktadır (Pierce vd., 1991: 125). Araştırmacılara göre bu haklar sahipliğin duygusal yönünü geliştirmektedir. Dolayısıyla bu haklar işgörene tanınmadığın da ortaklık planları istenilen sonuçlara ulaşamamaktadır. Pierce vd.'nin (1991) psikolojik sahiplenme olarak kavramsallaştırdıkları bu olgu ile birlikte sahiplik olgusuna ilişkin araştırmalar üçüncü evreye geçmiştir. Aslında finansal sahipliğin olumlu işgören tutum ve davranışları üreteceği bağlamında çöküşünü ifade eden bu üçüncü ve son dönem, resmi sahiplik iddiası olmadan da sadece sahipliğin kişiye sağlamış olduğu haklar üzerinden işgörenlerin işlerine ve örgütlerine karşı sahiplenme hissedebilecekleri ortaya çıkarmıştır.

Örgütsel bağlamda Psikolojik Sahiplenme araştırmalarının kökeni insan gelişimi, psikoloji ve sosyoloji yazınlarına dayanmaktadır. Ancak örgüt araştırmalarının olarak psikolojik kökeni temsil eden çalışmalar ekseninde geliştiği söylenebilir. Dolayısıyla işgören üzerinde psikolojik sahiplenme hissini ortaya çıkaran güdüleyicilerin neler olduğu üzerine yoğunlaşmıştır (Dirks,2003; Pierce vd., 2004; Pierce ve Rodgers, 2004; Van Dyne ve Pierce, 2004; Mayhew vd., 2007). Teori geliştirme kaygısı ile hareket eden çalışmalar da görülmektedir (Pierce vd., 2001; Van Dyne ve Pierce, 2004;Avey vd., 2009; Pierce ve Jussila, 2010). Özellikle de Pierce ve Jussila'nın (2010) ele almış oldukları kolektif psikolojik sahiplik kavramı, alanın sosyolojik temelde de ele alınabileceğine işaret etmektedir. 


\section{Z.UÇAR \\ 2.1.Psikolojik Sahiplenme Kavramının Tanımı, Boyutları Ve Türleri}

Yönetim uygulamacıları ve giderek artan sayıda örgüt bilimci, belirli koşular altında işgörenlerin yapmış oldukları iş ve çalışmakta oldukları örgüte karşı sahiplenme hissi geliştirdiklerini iddia etmektedir (Pierce vd., 2004: 507). Nitekim psikolojik bir olgu olarak sahiplenme, son dönemlerde bir çok araştırmaya konu olurken (örn., Pierce, Kostova ve Dirks, 2001; Dirks,2003; Pierce vd., 2004; Pierce ve Rodgers, 2004; Van Dyne ve Pierce, 2004; Mayhew vd., 2007), özellikle de işgörenleri çalışmış oldukları örgüte bağlayan psikolojik etkileri bağlamında zengin bir içerik sağlayacağı yönünde ortak bir bakış açısının oluştuğu da görülmektedir.

Psikolojik sahiplenme literatüründe "hedef" (target) teriminin oldukça geniş bir kullanım alanına sahip olduğu anlaşılmaktadır. Ditmar (1992), insanların, çeşitli somut ve soyut hedeflere ilişkin sahiplik duygusu hissettikleri andan itibaren kişinin hedefe yönelik bir yakınlık hissine kapıldığını belirtmektedir. Bu hedef bazen şirket kafeteryasında oturma yeri olarak tercih edilen küçük bir koltuk olabileceği gibi bazen de bir bütün olarak tüm endüstri veya örgüt olabilmektedir. Örneğin, bir işyerinde bir tekniker için sahipliğin hedefi tercih etmiş olduğu bir bilgisayar programı ya da bir alet seti olabilmekteyken, bir mühendis için belirli bir ürünün dizaynı olabilmektedir; ya da bir yönetici daha özelde örgütün stratejik önceliklerine, misyonuna, bir fikre sahiplenme hissedebilmektedir. Sahiplenilen hedef, kişinin kendisinin bir uzantısı olarak görülmekte ve kişinin benliği içerisinde çok köklü bir hale gelebilmektedir. Daha açık bir ifade ile sahiplik ve benlik çok fazla ilişkilidir. Örneğin kişinin kendi toprağının sınırlarını çizmesi ya da savunması kendinin bir uzantısı olarak değerlendirdiği hedefi savunmasının ve tanımlamasının bir yolu olmaktadır (Avey, 2009: 174,175). 
Avey vd. (2009: 174), psikolojik sahiplik olgusuna kavramsal bir çerçeve oluşturabilmek için öncelikle PS'nin amaç ve varsayımlarının tanımlanmasının gerektiğini belirtmektedirler. Pierce vd. (1991) psikolojik sahiplenmenin özünü, sahiplenme duygusu ve psikolojik olarak bir nesneye bağlı olma durumu olarak belirtmektedir. Bu bağlamda herhangi bir varlık kişi için psikolojik anlamda bir zemine oturduğunda o varlık kişi için "benimki” hüviyetine bürünür ve kişi kendini onun içinde var ettikçe varlıkta kişinin benliğine yerleşmektedir. Sonuçta hedef nesne, psikolojik sahiplik kimliğinin bir parçası haline gelmektedir (Pierce vd. (2001: 299) .

Dış yazında "psychlogical ownership" olarak kavramsallaştırılan bu olgu Van Dyne ve Pierce (2004: 439) tarafından potansiyel olarak olumlu iş gören tutum ve davranışların önemli bir tahminleyicisi olarak görülmektedir.

Pierce vd. (2001) tarafından örgütsel düzlemde ele alınan (Pierce vd., 2004: 511) PS olgusu, belirli koşullar altında işgörenlerin çalışmış oldukları örgüte ve çeşitli örgütsel faktörlere ilişkin geliştirdikleri sahiplik hissi olarak tanımlanmaktadır. Ayrıca kişinin kendini sahipliğin odağında yada sahipliğin bir parçasıymış gibi hissetmesinin bir ifadesi olarak da değerlendirilmektedir (Pierce vd., 2001: 298, 299).

Mahhew vd. (2007: 477) psikolojik sahiplenmeyi, mülkiyet hakkının resmi ya da yasal iddiasının yokluğundaki sahiplenme duygusu olarak tanımlamaktadır.

Bir diğer tanımda Vandewalle vd. (1995: 211) PS'yi, “işgörenlerin yasal/finansal bir sahiplikleri olmamasına rağmen iş ve örgütlerine karşı sahiplenme duyguları hissetmelerini temsil etmektedir." şeklinde tanımlamaktadır. 


\section{Z.UÇAR}

Araştırmalarında diğer çalışmalardan farklı olarak sahip olma durumu üzerine odaklandıklarını belirten Van Dyne ve Pierce (2004: 440) psikolojik sahiplenmenin sahiplenici doğası nedeniyle diğer örgütsel düzenle ilişkili işgörenlerin işe yönelik diğer tutum ve davranışlarından (örn. İş tatmini ve Örgütsel bağlılık gibi) farklılaştı̆̆ını belirtmektedirler. Weiss ve Cropanzano (1996) tarafindan geliştirilen Duygusal Durumlar Teorisi'ni psikolojik sahiplenmeye uyguladıklarını belirten yazarlar, bu sayede psikolojik sahiplenmenin doğasında bulunan farklı güdüleyicilerine bağlı olarak açıklayıcılık gücünün diğer işe yönelik tutum ve davranışlardan farklılaştığını iddia etmektedirler.

Psikolojik sahiplenmeye ilişkin bu temel güdüleri araştıran Pierce vd (2001), psikolojik sahiplenme boyutları diye tanımladıkları üç temel güdü ortaya koymuşlardır. Bu güdülerden ilki belirli durum ve çevre üzerinde kişilerin kontrol arzusunu ifade etmektedir. İkinci temel güdü ise bireyin diğer kişilere kendini tanımlama, öz-kimliğini ifade etme ve zaman içinde öz devamlılığ́ sağlamasını ifade etmektedir. Son güdü ise bireyin bir alan ya da belirli bir bölgeye sahip olma arzusunu (örn. bir eve sahip olmak gibi) belirtmektedir. $\mathrm{Bu}$ temel güdülerin her biri direkt olarak psikolojik sahiplenme olgusunu etkilemiyor olsa dahi, psikolojik sahiplenme davranışının gelişmesine katkı sağlamaktadır (Pierce vd. 2001: 300). Bu boyutlardan farklı olarak Avey vd. (2009) yeni bir boyut olarak değerlendirdikleri "sorumluluk” boyutunu ortaya koymaktadırlar.

Etkililik ve Etkileme: $\mathrm{Bu}$ temel güdünün altında yatan ana neden geniş bir kısımda kontrol sahibi olma isteğidir. Sahiplik ve bu durumun sağladığ 1 haklar kişilerin çevrelerini keşfetme ve değiştirmelerine izin verir. $\mathrm{Bu}$ şekilde kişiler doğalarındaki başarılı olma ihtiyacından dolayı tatmin olmaktadırlar. Kişinin kontrol veya eylemleri sonucunda istenilen çıktılar elde edildikçe etkililik duygusu, memnuniyet ve dişsal bir tatmin 
oluşmaktadır. Çevreyi değiştirmede nedensel etkililiği yaşama arzusu, sahip olma girişimlerine ve sahiplik hislerinin ortaya çıkmasına neden olmaktadır (Pierce vd. 2001: 300).

Öz-Kimlik: Pierce vd. (2001: 300) insanların öz-kimliklerini ve bireyselliklerini yakın bir biçimde ilişkilendirdikçe, sahiplenmenin benliğin sembolik bir ifadesi olarak hizmet ettiğini belirtirken Avey vd. (200: 174) öz kimliğin sosyal kimlikle birlikte benlik kavramı alanının büyük bir kısmını tanımladığını belirtmektedir (Avey vd., 2009: 174). Bu bakımdan insan grupları ve sahip olunan varlık (mal, mülk vb.) insanların kendilerini ne şekilde tanımladıklarına ilişkin bir sembol olarak değerlendirilmektedir (Avey vd., 2009: 174). Diğer bir ifade ile insanlar sahip oldukları ile diğer kişilere kendi kendilerini tanımlama, öz-kimliklerini ifade etme ve zaman içinde öz devamlılıklarını sağlamayı amaçlamaktadırlar(Pierce vd. 2001: $300)$.

Bir Alana Sahip Olma: Sahiplik ve ilişkili olduğu psikolojik durum, kişi tarafından belirli bir bölge veya alana sahip olmayla kısmen izah edilebilecektir (örn. bir evim var gibi). Kişi potansiyel olarak kendisinin olabilecek hedefe yönelik enerji ve kaynak harcadığı sahiplik sayesinde bu güdüsünü tatmin edecektir (Pierce vd., 2001: 300).

Sorumluluk: Sorumluluk, Larner ve Tetlock (1999: 225) tarafindan kişinin inançları, duyguları ve aksiyonlarını diğer kişilere onaylatmak için başvurabileceği gizli ya da açık beklentiler olarak ifade edilmektedir. Sorumluluğun ilk olarak iki mekanizmayla psikolojik sahiplenmenin bir bileşeni olarak dikkate alınabileceğini belirten Avey vd., (2009: 177) bunları diğerlerini sorumlu tutmaya ilişkin beklenti ve kişinin kendini sorumlu olarak tutma beklentisi olduğunu belirtmektedirler. 


\begin{abstract}
Z.UÇAR
Mahhew vd. (2007: 477) yapmış oldukları çalışmada psikolojik sahiplenmenin iş yeri düzleminde iki farklı şekilde çıktığını iddia etmektedirler. Bunlar iş tabanlı psikolojik sahiplenme ve örgüt tabanlı psikolojik sahiplenmedir. Yazarlar ayrıca bu iki sahiplenme türünün de iş tatmini ve örgütsel bağlılıktan farklı ve ayırt edilebilir tutumlar olduğunu belirtirken, psikolojik sahiplenmenin olumlu işgören davranışlarının gelişmesini sağlayan bir olgu olduğunu aktarmaktadırlar.

Pierce vd. (2001) psikolojik sahiplenmenin destekleyici ve önleyici olmak üzere iki odağa sahip olduğu belirtirken, Avey vd.'nin (2009: 175) psikolojik sahiplenmenin bu bağımsı iki biçimini incelemek için Higgins'in düzenleyici odak teorisi temelinde konuyu ele aldıkları görülmektedir. Higgins'e göre öz-düzenleme kişinin amaçlarını seçmesini ifade etmektedir. Destek odaklı yaklaşımlar kişilerin umut ve isteklerini arttırma yönünde hareket etmektedir. Diğer taraftan önleyici odak yaklaşımlar ise cezalandırma, kuralları ve yükümlülükleri çiğneme durumlarını azaltmaya yönelik bu durumlardan nasıl kaçınılacağı üzerine odaklanmaktadır. Ayrıca Higgins, destekleyici ve önleyici odakların her ikisine de insanoğlunun hayatta kalabilmesi için ihtiyaç duyulduğunu belirtmekte ve bir odağın diğer bir odaktan daha fazla arzu edilebilir bir yaklaşım olmadığını iddia etmektedir. Örneğin belirli koşullarda destekleyici odak geliştirme ve iyileştirme açısından gerekli iken, farklı koşullar bireylerin istikrarı koruma, güvenlik sağlama ve öngörü yapabilmeleri bağlamında koruyucu odağını daha fazla gerektirebilmektedir.

Her iki odak da psikolojik sahiplik araştırmalarına uygulandığında, destek odaklı ya da önleyici odaklı kişiler hedefe yönelik oldukça farklı hisler deneyimleyebilirler. Örnek olarak, bilgi paylaşımının bir şirketin içindeki başarı ve değişime neden olduğu bir örnek olayda, destek odaklı psikolojik sahiplik sergileyen bir yönetici, kişisel olarak şirketin gelişimi
\end{abstract}


açısından memnuniyet verici olarak gördüğü başarılmış bir projeden sonra örgüt içindeki farklı birimlerdeki topluluklar veya takımlar ile bilgi paylaşımına karar verebilir. Buna karşın önleyici odağa sahip bir yönetici dikkatli bir şekilde izlemeye ve diğerlerinden bilgileri saklamaya karar verebilir çünkü bu tip bireyler değişimden kaçınırlar ve var olan dengenin devamını arzu ederler (Avey, 2009: 175,176).

Psikolojik sahiplenme yazınının halen yeterince olgunlaşmadığına vurgu yapan Avey vd. (2009), çalışmalarında kavramın daha kapsamlı bir tanımının yapılması ve çok boyutlu bir psikolojik sahiplenme ölçeği geliştirmeyi amaçladıklarını belirtmektedirler. Liderlik davranışları, psikolojik sahiplenme davranışını etkileyen bağlamsal bir faktör olarak değerlendiren Avey vd. (2009: 174) çeşitli liderlik özelliklerinin liderin takipçileri olarak işgörenlerin psikolojik sahiplenmesi üzerinde olumlu etki yapacağını belirtirken, diğer bir kısım liderlik özelliklerinin de bunun tam tersi bir etki yapabileceğini belirtmektedirler. 


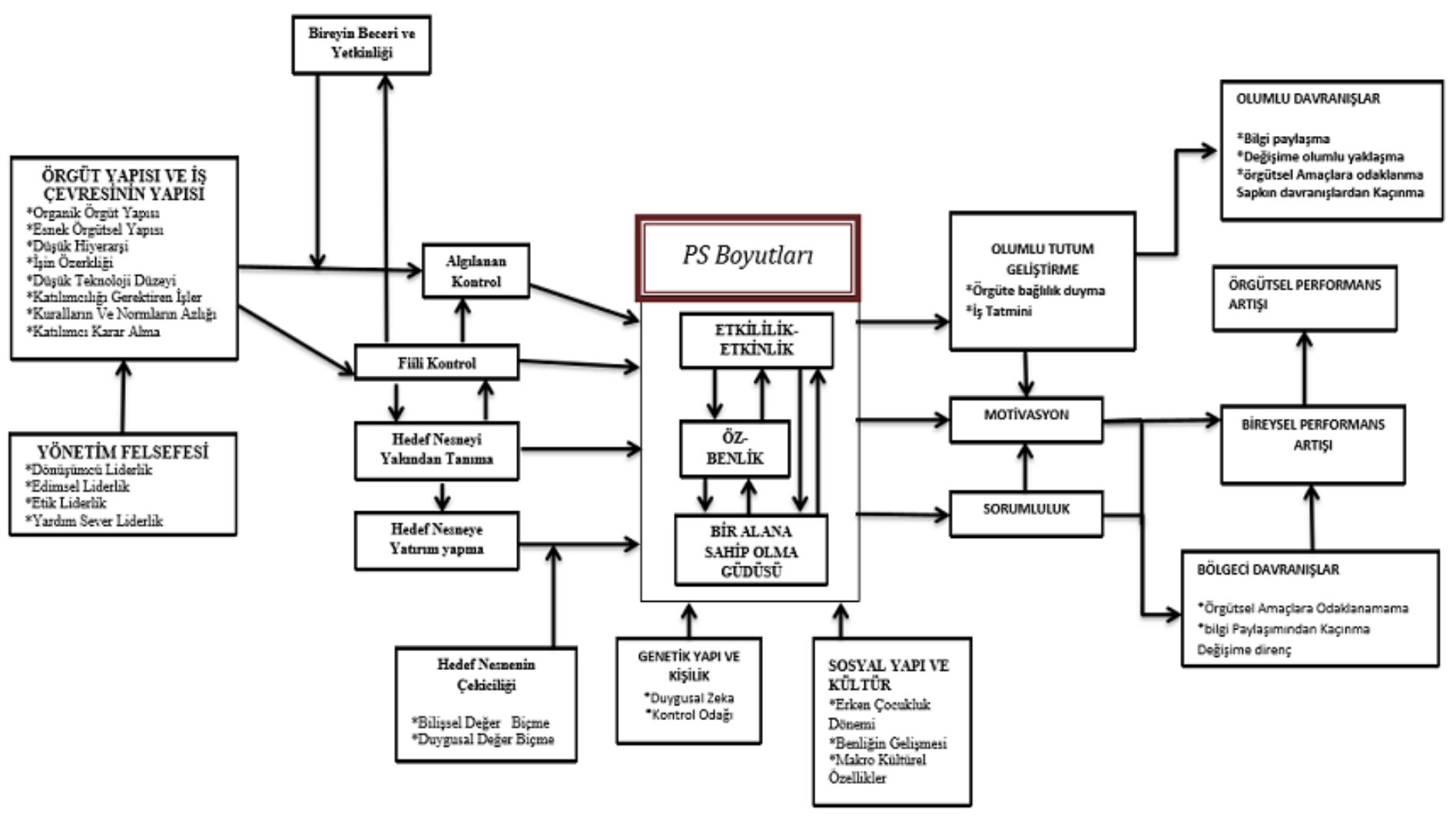




\section{MODELE ILISSKIN KURAMSAL VE BETIMLEYICİ AÇIKLAMALAR}

Pierce vd. (2001: 298) belirli koşullar altında işgörenlerin örgütlerine ve çeşitli örgütsel faktörlere yönelik olarak sahiplik duygusu geliştirebileceklerini belirtmektedirler. Özelliklede organizasyon yapısı işgörenlerin yaptıkları işi ve örgütlerini sahiplenmeleri bağlamında zengin bir içerik sunmaktadır. O'driscoll vd. (2006: 390) işgören duygu, motivasyon ve davranışlarının olumlu veya olumsuz bir şekilde organizasyon yapısı tarafından etkileneceğini belirtmektedir. Liderlik özelliklerinin örgüt yapısı üzerine etkileri dikkate alındığında olumlu veya olumsuz yönde gelişen işgören tutum ve davranışlarının liderlik özelliklerinden etkilendiği ulaşılması muhtemel bir durumdur. Psikolojik sahiplenme ve liderlik tip ve özellikleri arasındaki ilişkileri araştıran çeşitli çalışmalar liderlik tip ve özelliklerinin psikolojik sahiplenmeyi etkilediğini ortaya koymaktadır( örn. Avey vd., 2009; Ghafoor vd., 2011; Bernhard ve Driscoll, 2012; Zhu vd., 2013; Avey vd., 2012). Bu araştırmalarda dönüşümcü liderliğin psikolojik sahiplenme üzerindeki etkisi (Avey vd., 2009; Ghafoor vd., 2011; Bernhard ve O’Driscoll, 2011) tarafindan, edimsel liderliğin psikolojik sahiplenme üzerindeki etkisi (Bernhard ve O’Discroll, 2011) tarafından, etik liderliğin psikolojik sahiplenme üzerine etkisi (Avey vd., 2012) tarafından ve yardımsever liderliğin psikolojik sahiplenme üzerine etkisi (Zhu vd., 2013) ve hizmetkar liderliğin psikolojik sahiplenme üzerindeki etkisi ise (Yıldız ve Yıldız, 2015) tarafından ortaya konmuştur. $\mathrm{Bu}$ araştırmalar içerisindeki çeşitli liderlik özelliklerinin işgörenlerin duygu ve davranışları üzerinde açık etkileri olduğu görülmektedir. Kimi liderlik özellikleri işgörenlerin yapmış oldukları iş ve örgütleri üzerindeki öz etkinliklerini, mesuliyet ve sorumluluk hislerini 


\section{Z.UÇAR}

arttırmakta ve yapmış oldukları işleri ve içerisinde çalışmış oldukları örgütlerini benlikleriyle bütünleştirmelerini sağlamaktadır. Nitekim yazın içerisinde psikolojik sahiplenmenin boyutları olarak değerlendirilen bu olgular üzerindeki liderlik etkisi, işgörenlerin yapmış oldukları iş ve örgütlerine karşı sahiplenme hissi geliştirmelerini etkilemektedir. Ancak psikolojik sahiplenme üzerindeki liderlik etkisini sadece doğrudan bir etki olarak değerlendirmemek gerekmektedir. Çünkü lider davranışlarının dışa yansımasının toplamı olarak değerlendirilen yönetim felsefesi ile örgüt yapı ve özellikleri arasında çoğu zaman sıkı bir ilişki olduğu bilinmektedir. Nitekim Pierce vd.'ne göre (2003) işgörenlerin sahiplenme hisleri, norm, kural, hiyerarşi, uzmanlaşma, standartlaşma, merkezileşme gibi unsurların örgütsel düzeyine bağlı olarak ortaya çıkmaktadır. Özellikle işlerin aşırı standartlaştığı ve çalışanların tek tip davranışlar sergilemelerinin beklendiği katı ve mekanik örgüt yapıları, bir yandan bireylerin psikolojik sahiplenme için gerekli güdülerini bastırmalarına neden olurken diğer taraftan psikolojik sahipliğin gelişmesine katkı sağlayan mekanizmaların oluşmasını da engellemektedir (Pierce vd., 2003: 24,25).Yine farklı bir çalışmada O’driscoll vd.(2006: 389) daha az yapılandırılmış iş çevrelerinin işgörene daha fazla kontrol ve özerlik yetkisi tanıdığından hareketle, yapılandırılmamış iç çevresinin çalışanların örgüt ve işlerine yönelik daha fazla psikolojik sahiplenme sağladığını belirtmektedirler. Dolayısıyla örgüt yapı özellikleri ve iş çevresi özelliklerinin PS'yi etkileyen temel değişkenler olduğu anlaşılmaktadır.

Bununla birlikte Pierce vd.nin (2009: 478) psikolojik sahiplenmeyi iş dizaynı teorisi'ne(Hackman ve Oldham, 1975) doğru genişleterek, psikolojik sahiplenme teorisine yeni ve geniş bir bakış açısı sağladıkları görülmektedir. Araştırmacıların standartlaşma, iş basitleştirme ve 
uzmanlaşma gibi iş yapılarını tanımlayan iş özelliklerinden ziyada kompleks şekilde dizayn edilmiş işlere odaklandıkları görülmektedir. Yazarlara göre daha karmaşık iş yapılarının kişilere daha fazla özerlik sağlayarak yapmış oldukları işi kendilerine göre dizayn etme firsatı (kendi isteklerine göre ticarileştirme ve kişiselleştirme bağlamında) sağlamaktadır. Çünkü böyle yapılar içerisinde bireyler hedef nesne üzerinde bazı haklar (kontrol, etkinlik vb.) elde etmekte, hedef nesneyi daha yakından tanımakta ve ona enerji ve zaman harcamaktadır. O nedenle örgüt yapı özellikleri ile iş çevresi yapısının bireye sağlamış olduğu hak ve sorumluluklardan dolayı psikolojik sahiplenmeye etki ettiği sonucuna ulaşılabilir. Nitekim, bazı araştırmacılar belirli bir nesne için sorumluluk üstlenmenin (çalışanın, enerji, zaman, bakım yapma, endişelenme ve dikkat kesilmesi gibi) sahiplenme duygusuna yol açtığını belirtmektedirler (Pierce vd., 2004: 510). Bununla birlikte Pierce vd. (2003: 18) göre sahiplenme psikolojisinin temelinde hedef nesneyi kontrol, yakından tanıma ve benlikle bütünleştirme yatmaktadır. Dolayısıyla psikolojik sahiplenme hissinin gelişebilmesi için bazı mekanizmaların varlığı gerekli olmaktadır. Konuyu bu eksende değerlendiren Pierce vd. (2001), hedef nesne üzerindeki kontrolün, hedef nesneyi yakından tanımanın ve hedef nesneye öz yatırım yapmanın psikolojik sahiplenmenin oluşumunu sağlayan temel mekanizmalar olduğunu belirtmektedirler. Ancak hedef nesne üzerindeki kontrol algısının, yönetim felsefesi, örgüt yapı ve özellikleri ile iş çevresi yapısınca şekillenen özerklik üzerinden geliştiği önemli bir nokta olarak açığa çıkmaktadır. Özerklik kavram olarak kişinin kendini yönetmesini ve kişinin kendi tarafından yapılan öz düzenlemeyi ifade etmekte (Deci ve Ryan, 1987; Ryan ve Deci, 2006) ve PS araştırmalarında sıklıkla kullanılmaktadır. İş çevresi ve PS' ye ilişkin yapmış oldukları araştırmada, kontrolün özerklik ve PS 


\section{Z.UÇAR}

arasında aracı rolü olduğunu bulgulamışlardır. Bu bulgulara ek olarak, özerkliğin hem örgüte yönelik hem de işe yönelik PS'nin oluşumunda etkisi olduğunu bulgulanırken Mathew vd. (2007); Pierce vd. (2009) tarafindan özerlik PS'nin oluşumuna katkı sağlayan bir öncül olarak değerlendirmektedir. Bu araştırmaların dışında Olckers ve DuPlessis (2012) özerliğin PS'nin boyutları içerisinde değerlendirilmesi gerektiğini belirtmektedirler. Ancak modelde de açık bir biçimde ortaya konmuş olduğu gibi özerklik kontrol üzerinden PS'yi etkilemektedir. Nitekim araştırmacının bilgisi dahilinde yazında ampirik kanıtlara ulaşılamadığı gibi bu önermeyi mantık temelinde destekleyecek kuramsal çalışmalara da rastlanmamıştır.

Hedef nesne üzerindeki kontrolü, etkililik ve öz benlik güdüleriyle ilişkilendiren Pierce vd. (2001), hedef nesne üzerindeki kontrolün o nesneye karşı sahiplenme hissinin gelişmesinde önemli bir araç olduğunu belirtmektedirler (Pierce vd., 2001: 301; Pierce vd., 2003: 14). Kontrol sayesinde birey nesne üzerinde etkili olma güdüsünü tatmin etmekte ve onu benliğiyle bütünleştirerek benliğinin bir bileşeni haline getirmektedir. $\mathrm{Bu}$ nedenle Pierce vd.'nin de (2001: 301) belirtmiş oldukları gibi bireyin hedef nesne üzerindeki kontrolün düzeyi ile hedef nesneyi sahiplenme düzeyi arasında pozitif yönde anlamlı ve nedensel bir ilişki olduğu anlaşılmaktadır. Hedef nesneyi yakından tanımaya ilişkin olarak Pierce vd. (2001: 301), bireyin hedef nesneyle olan bağlantısı, onun hakkında bilgi sahibi olması, onunla canlı bir ilişki sürdürmesi bireyin hedef nesneye karşı psikolojik sahiplenme hissinin oluşmasına zemin hazırladığını belirtmektedirler. $\mathrm{Bu}$ noktada bireyin hedef nesneyle geçirdiği zaman, onun hakkında bilgi sahibi olmasına ve onu yakından tanımasına neden olduğundan, hedef nesnenin benlikle bütünleşmesini sağlamaktadır. Dolayısıyla işgörenlerin işler, projeler, süreçler ve önemli örgütsel amaçlarlar gibi somut ve soyut hedefler 
hakkında bilgi sahibi olmaları, hedef nesneyi daha yakından tanımalarına ve bu hedeflere karşı psikolojik sahiplenme hissi geliştirmelerine katkı sağlamaktadır (Pierce vd., 2001: 302). Sonuç olarak biçimselleşme, uzmanlaşma ve standartlaşma derecesinin düşük olduğu organik örgüt yapıları ve âdemi merkezi yapıya sahip örgütler işgörenin hedef nesneyi kontrol etmesine, hedef nesneyi yakından tanımasına ve hedef nesneye öz yatırım yapmasına imkân tanımaktadır. Bu durum bireyin etkinlik ve etkililik, öz-kimlik ve bir alana sahip olma güdülerinin tatminine katkı yaparak psikolojik sahiplenme hissinin gelişmesini sağlayacaktır. Örneğin iş dizaynı ve işgören tepkisi ilişkisinde önerilen psikolojik durumların (örn. algılana işin anlamsızlığı, iş sonuçlarına ilişkin algılanan sorumluluk vb.) daha iyi bir ara değişken etkisi gösterebilecektir. İşinin üzerinde daha fazla kontrol sahibi olan işgörenlerin muhtemel olarak iş eksenli psikolojik sahiplenmeleri daha fazla gelişecektir. Geri bildirim, görev kimliği ve özerklik, kişi ve iş arasında samimi bir bağın oluşmasına neden olacak ve muhtemel olarak iş eksenli psikolojik sahiplenmeyi attıracaktır.

Burada önemli bir nokta işgören beceri ve yetkinliğinin kontrolü etkileyen değişkenler ve kontrol düzeyi arasındaki ilişkideki düzenleyici etkisidir. Çünkü bireyin hedef nesneye yönelik beceri ve yetkinlikleri hedef nesne üzerindeki fiili kontrol düzeyini arttıracaktır. Nitekim,Ghafoor vd. (2011: 7395) bireylerin iş ve örgütleriyle bütünleşmelerinin PS'nin oluşmasında önemli bir unsur olduğunu belirtirken iş veya görevlere yönelik beceri ve yetkinliklerin PS'yi arttıracağını belirtmektedir. Bununla birlikte beceri ve yetkinliklerin hedef nesne üzerinde bireyin algılamış olduğu kontrol düzeyini de etkilediği düşünülebilir. Çünkü beceri ve yetkinlikler birey ve hedef arasındaki ilişkinin oluşumunda hızlandırıcı etki yapacaktır. Nitekim,PS'nin oluşumunda algıların önemli bir yeri olduğunu belirten Lee 


\section{Z.UÇAR}

ve Chen (2011), bireyin hedef nesne üzerindeki algılamış olduğu kontrolün PS oluşumuna etkisi olduğunu bulgulamışlardır. Sonuç olarak bireyin hedef nesne üzerindeki kontrol düzeyi arttıkça hedef nesneyi daha yakından tanıma imkânı bulacak ve hedef nesneye yönelik beceri ve yetkinlikleri de bu duruma bağlı olarak gelişecektir.

Dikkate alınması gereken bir diğer önemli nokta da hedef nesneyi yakından tanıma ve hedef nesneye öz yatırım yapmanın ancak fiili kontrolden sonra gerçekleşebileceğidir. Birey hedef nesne üzerinde kontrol sağladıktan sonra hedef nesneyi yakından tanımakta ve hedef nesnenin algılanan çekiciliğinin düzenleyici etkisine de bağlı olarak hedefe öz yatırım yapmaktadır. Psikolojik sahiplenmeyi (örn., benimki ve/veya bizimki olarak ifade edilen kişisel duygu durumu) kompleks bir durum olarak değerlendiren Pierce vd. (2009) göre psikolojik sahiplenme bilişsel ve duygusal temellerden oluşmaktadır. Bilişsel temel, sahipliğin hedefi ile ilgili olarak kişinin farkındalığı, düşünceleri ve inançları doğrultusunda hareket etmekteyken, duygusal temel ise başlı başına kişinin almış olduğu hazla ilgilidir (Pierce vd., 2009: 481). Nitekim Pierce vd. (2003) hedef nesnenin çekiciliğinin onu sahipliğin ideal adayı haline getirdiğini belirtirken, doğrudan bir etkiden söz etmemektedir. Ancak Lee vd. (2011) bilişsel ve duygusal değer biçmenin (hedefin çekiciliğinin) psikolojik sahiplenmeyi doğrudan etkilediğini belirtmektedir. Her ne kadarda hedef nesnenin çekiciliğiyle psikolojik sahiplenme arasında ilişki Lee ve Chen (2011), tarafından doğrudan tanımlanmış olsa da, kanımızca bu durum hedefi yakından tanıma ve hedefe öz yatırım yapma ilişkisi üzerindeki düzenleyicilik etkisinden kaynaklanmaktadır. Çünkü hedef nesneye duygusal ya da bilişsel anlamda biçilen değer (hedefin birey açısından çekiciliği) kontrol, hedefi yakından tanıma ve hedefe öz yatırım yapma 
durumlarından da bağımsız gelişebilecek bir durumdur. Örneğin örgüt içerisinde işgörenler tarafindan duygusal ve bilişsel anlamda önemli düzeyde değer biçilen bir iş yada bir pozisyon, bu genel algıyı hisseden diğer işgörenler tarafından da hissedilebilecektir. Dolayısıyla Pierce vd.'nin de (2003: 20) belirtmiş oldukları gibi birey diğerleri nezdinde hangi hedef nesnenin önemli olduğunu düşünerek, o hedef nesneye yönelik psikolojik sahiplenme hissine hazır hale gelebilir. $\mathrm{Bu}$ nedenle hedefin çekiciliğinin PS'nin gelişmesinde doğrudan etkisinden çok kontrol, hedefi yakından tanıma ve hedefe öz yatırım yapma ile PS ilişkisinde düzenleyici bir etkisinin olduğundan bahsedilebilir.

Bir diğer önemli nokta ise fiili kontrolle birlikte hedef nesneyi yakından tanımaya başlayan bireyin hedef nesneye yönelik bilgisinin artısına bağlı olarak beceri ve yetkinliklerinin de gelişmesidir. Bu bağlamda hedef nesne üzerinde beceri ve yetkinliği gelişen bireyin hem hedef nesne üzerindeki fiili kontrolü artmakta hem de algılamış olduğu kontrol düzeyi olumlu yönde gelişmektedir.

Pierce vd. (2004), yapmış oldukları çalışmada iş çevresi yapısı ve psikolojik sahiplenme arasındaki ilişki üzerinde kişinin algılamış olduğu kontrolün düzenleyici etkisini araştırmışlardır. $\mathrm{Bu}$ araştırmada yazarlar iş çevresi yapısına ilişkin olarak teknoloji, otonomi ve katılımcı karar verme ve iş ve örgüte yönelik PS arasındaki ilişkiler üzerinde algılanan kontrolün düzenleyici etkisinin olduğunu bulgulamışlardır. Dolayısıyla fiili kontrol ve PS arasında algılanan kontrolün düzenleyici bir etkisi olduğu da söylenebilir.

Genel olarak araştırmaların, PS olguya ilişkin iki farklı yaklaşım benimsediği görülmektedir. Bunlardan birincisi PS olgusunun bir kişilik 


\section{Z.UÇAR}

özelliği olduğu tezi üzerine yoğunlaşırken, ikincisi ise kişinin bazı deneyimleri sonucunda sonradan gelişen bir durum olduğu iddiasıdır. Ancak yapılan üç değişkenli (bağımsız, ara ve sonuç değişkenleri) çalışmalarda PS'nin ara değişken olarak farklı değişkenler arasında aracılık rolünün irdelendiği görülmektedir. Bu durum ikinci durum göz önüne alındığında mantıklı bir model oluşturma açısından uygun gözükmektedir. Ancak birinci durum baz alındığında; yani psikolojik sahiplenmenin bir kişilik özelliği olduğu varsayımı altında,PS'nin sadece ara değişken olarak çalışmalarda yer bulması, mantık düzleminde sağlam bir zemine oturmamaktadır. Çünkü, zaten bireyde var olan bir kişisel özelliğin belirli durumlardan etkilenmesi ne kadar olası ise, kişide var olan bu özellikle sonuç değişkenleri arasındaki ilişkinin bu belirli durumların düzenleyici yönünden etkilenmesi de o kadar olası gözükmektedir. Sonuç olarak yapılan çalışmaların sahiplenme duygusunu kişisel bir özellik olarak değil aslında farklı kişilik özelliklerinin düzenleyici etkisiyle gelişen bir olgu olarak değerlendirdikleri anlaşılmaktadır.

Çalışmalarında psikolojik sahiplenmenin kökenlerini araştırdıklarını belirten Pierce vd. (2001) ve Pierce vd. (2003) öncelikle psikolojik sahiplenmenin niçin var olduğunu ve spesifik olarak bu durumun güdüleyicilerinin neler olduğunu veya bu durumun kişilere ne şekilde hizmet ettiği üzerine odaklanmışlardır. Yazarlar, bu sorulara yanıt olarak bazı araştırmacıların kişilerin genetik yapıları üzerinden hareket ettiklerini, diğer bir kısım araştırmacıların ise bu durumu, insan gelişimi ile ilgili bir konu olarak ele aldıklarını belirtmektedirler (Pierce vd.,2001:300; Pierce vd., 2003: 2-8). Ancak araştırmacılar kendi araştırma bulgularına bağlı olarak psikolojik sahiplenmenin köklerinin üç temel güdü üzerinde bulunabileceğini belirmektedirler. $\mathrm{Bu}$ temel güdüler: (1) “etkililik ve 
etkileme”, (2) “öz-kimlik", ve (3) "bir yere sahip olma“ dır. Pierce vd. (2001) tarafindan teorik temelleri atılan psikolojik sahiplenme güdülerini, psikolojik sahiplenmenin boyutları olarak değerlendiren Avey vd. (2009) alana ilişkin teorinin gelişmeye ihtiyacı olduğunu belirtirken çalışmalarında psikolojik sahiplenmeye ilişkin yeni bir boyut olan "sorumluluk" (accouantability) boyutunu yazına kazandırmışlardır.

Yine kişilik özellikleri ile alakalı olarak, Kaur vd. (2013) yapmış oldukları araştırmada kişilerin ruhsal ve duygusal zekâlarının PS'yi etkilediğini belirtmektedirler. Araştırmacılara göre PS doğası gereği içsel olarak çevreyi etkileme ihtiyacı ve çevreyi kontrol etme isteği ile yakın bir ilişki içerisindedir. İçsel kontrol odağıyla açıklamış oldukları bu duruma bağlı olarak, yüksek ruhsal ve duygusal zeka bireysel kontrol algısını artırmakta ve psikolojik sahipliğin gelişimine katkı sağlamaktadır (Kaur vd.,2013, s. 3195).

Modeli açıklamaya ilişkin araştırmanın bu kısmına kadar yapılmış olan açıklamalar ve ulaşılmaya çalışılan sonuçlar, örgütsel ortamda PS'nin hangi değişkenlerin etkisi altında ne şekilde oluştuğunu açıklamaya çalışmaktadır. Ancak araştırmamızın sonraki kısımlarında PS'nin işgörenlerin tutum ve davranışları üzerinde ne gibi olumlu ve/veya olumsuz sonuçlarının olduğu yine model üzerinden tartışılacaktır.

Model üzerinde PS'nin değişkenler arasındaki aracılık etkisi açık bir biçimde ortaya konmuştur. Nitekim yapmış oldukları çalışmada yapılandırılmış ve yapılandırılmamış iş çevresinin psikolojik sahiplenmeyle ve olumlu örgütsel tutum ve davranışlarla (örgütsel vatandaşlık davranışı ve örgütsel bağl1lık) olan ilişkisini araştıran O'driscoll vd. (2006: 388) iş çevresi yapısı ile olumlu örgütsel tutum ve davranışlar arasındaki ilişki 


\section{Z.UÇAR}

üzerinde PS'nin aracı rolü olduğunu belirtmektedirler. Bir diğer araştırma da çeşitli aile şirketleri üzerinde gerçekleştirmiş oldukları çalışma ile liderlik sitillerinin psikolojik sahiplenme üzerinden ( iş eksenli - örgüt eksenli) işgörenlerin olumlu davranışları üzerindeki etkisini araştıran, Benhard ve O’Discroll (2012), psikolojik sahiplenmenin liderlik sitilleri ve işgören tutum ve davranışları arasındaki ilişkide aracılık rolünü ortaya koymaktadırlar. Araştırma sonuçlarına göre, işe yönelik lider ve dönüşümcü lider algısının psikolojik sahiplenme üzerinden işgören vatandaşlık davranışı, işgörenden beklenen rol, duygusal bağlılık, iş tatminleriyle olumlu yönde bir ilişki gösterirken, işgörenlerin işten ayrılma niyetleri (turnover intention) arasında ters yönde bir ilişki bulgulanmıştır. $\mathrm{Bu}$ noktadan hareketle işgörenlerin çalışmış oldukları işyerlerine karşı sorumluluk hissi ve olumlu tutumlar geliştirmeleri, motivasyonlarının ve bağlılıklarının artması PS'nin temel çıktıları olarak işgörenlerin olumlu davranışlarını etkilemektedir.

Literatürde PS ilgili olduğu değerlendirilen bir diğer olgu ise sorumluluk hissidir. Pierce vd. (2001: 303) göre bireylerin hedef nesneyi psikolojik olarak sahiplenmesiyle eşanlı olarak bireyin davranışlarını etkileyen bir sorumluluk hissi de gelişmektedir. Aslında ortaya çıkan bu durum yine yazın içerisinde ele alınan hedef nesneye karşı kendini mesul hissetmeyle (accountability-hesap verme zorunluluğu) de yakında ilişkili gözükmektedir. Nitekim hesap verme olgusunu PS ile birlikte ele alan Avey vd. (2009: 177), hesap vermenin iki şekilde ortaya çıtığını belirtmektedirler. İlki diğerlerini sorumlu tutabilme hakkı iken; diğeri bireyin eylemlerinin sonucundan sorumlu tutulabileceği beklentisi olarak ortaya çıkmaktadır. Aslında bu durumun bir tutum geliştirme ya da bir davranışa dönüşme olasılığına çok yakın olması sorumluluğun PS'nin bir 
sonucu olabileceği şüphesine de ortam hazırlamaktadır. Nitekim, bir kısım araştırmacıların da belirtmiş oldukları gibi sorumluluk hissi sahiplenilen hedef nesneye yönelik fazladan zaman ve emek harcamayı içsel olarak aktifleştirmektedir (Olckers ve duPlessis, 2012: 2590; Pierce vd., 2001: 303). Dolayısıyla sorumluluk PS'nin bir sonucu olarak olumlu tutum ve davranışlara ortam hazırlayan bir olgu olarak düşünülebilir.

Kubzansky ve Druskat (1993) sahiplik duygusu psikolojisinin işgörenlerin örgütleri ile ilişkilerinde önemli bir bölümü teşkil edebileceğini savunurken, Pierce vd. (1991), resmi sahipliğin, psikolojik olarak deneyimlenen sahiplik sayesinde olumlu tutum ve davranışları ortaya çıkarabileceğini belirtmektedirler (Pierce vd., 2001: 298). Nitekim finansal sahipliğe ilişin özellikler üzerinden psikolojik sahiplenmeye kavramına uzaman Pierce vd (1991), psikolojik sahiplenmeyi ekstra rol davranışlarını içeren yüksek düzey bir motivasyonla ilişkilendirmektedirler. Bu noktada PS ile birlikte geliştiği belirtilen sorumluluk hissinin içsel anlamda motivasyonu olumlu yönde etkilendiğinden söz edilebilir. Çünkü sorumluluk bireyi motive etmekte ve hedefe yönelik fazladan enerji harcamasına neden olabilmektedir. Ekstra rol davranışları olarak da ifade edebileceğimiz fazladan enerji harcama, Vandewalle(1995: 211) tarafından, örgüt yararına olan işe yönelik yapıcı çalışmalar ve işin gerektirdiği etkinliklerin ötesine geçme şeklinde tanımlanmaktadır. Vandewalle vd. (1995:211) çalışmalarında Pierce vd. (1991) ve Pierce vd.'nin (1992; 1994) yapmış oldukları çalışmalara atıf yaparak, psikolojik sahiplenmenin örgütler adına olumlu sonuçları olduğuna dikkat çekmektedirler. Bu bağlamda psikolojik sahiplenmenin, eşit olmayan finansal sahiplik durumunda dahi olumlu işgören davranışlarıyla ilişkili olduğu belirtilmektedir. 


\section{Z.UÇAR}

PS ve işyerine ilişkin diğer işgören davranışlarının birbirlerinden farklı olgular olduğunu belirten Van Dyne vd. (2004) psikolojik sahiplenme ile işgörenlerin örgütlerine yönelik tutum ve davranışları arasındaki ilişkiyi araştırmış oldukları çalışmalarında, psikolojik sahiplenme ile tatmin ve bağlılık arasında pozitif bir ilişki tespit etmişlerdir. Ayrıca psikolojik sahiplenme ile işe yönelik davranışlar olan örgütsel vatandaşlık davranışıyla pozitif yönde ilişkili bulgularken, örgütsel performans ile anlamlı bir ilişki bulgulanamamıştır. PS'nin örgütsel çıktılar üzerinde kayda değer sonuçlarının olduğu çeşitli araştırma sonuçlarıyla sabittir. Nitekim PS'nin olumlu iş gören tutum ve davranışlarına katkı sağladığı birçok araştırmada (Pierce vd., 1991; Wagner vd., 2003; Van Dyne ve Pierce, 2004; O’Driscoll vd., 2006; Avey vd., 2009; Han vd., 2010; Bernhard ve O’Driscoll, 2011; Liu vd., 2012; Avey vd., 2012; Sieger vd., 2013; Kaur vd., 2013; Zhu vd., 2013) ortaya konmuştur. Bu araştırmalardaki örgütsel çıktılar üzerine genel bir değerlendirme yapılacak olursa; PS'niniçsel bir motivasyon sağlayarak bireysel performansı arttırdığı ve dolayısıyla da örgütsel performansa katkı sağladığı değerlendirmesi ön plana çıkmaktadır. Ancak Van Dynevd.'nin (2004) çalışmasında olduğu performans konusunda farklı sonuçlara da ulaşıldığı görülmektedir. $\mathrm{Bu}$ durum aslında farklı ara değişken ya da düzenleyici değişkenlerin olabileceği şüphesini de ortaya çıkarmaktadır. $\mathrm{Bu}$ nedenle PS ve performans ilişkisini örgütsel alana ilişkin farklı ara yada düzenleyici değişkenlerle birlikte ele almak PS olgusunun teorileşmesine katkı sağlayacaktır.

İşgörenlerin çalışmış oldukları örgüte ve yapmış oldukları işe yönelik sorumluluk hissi ve olumlu tutumlar geliştirmeleri ve yine örgütlerine ve yapmış oldukları işlere katkı sağlamak için motivasyonel anlamda hazır hale gelmelerinin PS'nin temel sonuçları içerisinde olduğu 
görülmektedir. Ancak bu değişkenlerinde kendi aralarında ilişkili olduğu değerlendirilebilir. Sorumluluk hissi ve olumlu tutum geliştirmenin motivasyonel anlamda işgöreni hazır hale getirmesi olasıdır. Dolayısıyla da PS araştırmaları içerisinde işgören davranışının öncülü olarak değerlendirilen sorumluluk ve olumlu tutum geliştirme değişkenlerinin işgörenleri içsel anlamda hazır hale getiren motivasyon üzerinden davranışı şekillendirdiği ulaşılabilecek mantıklı bir sonuçtur.

Han vd. (2010: 2218) çalışmalarında, işgörenlerin kararlara katılımının, onların bilgiyi paylaşma davranışlarına etki ettiği düşünülen işgören olumlu alg1 ve tutumları üzerindeki etkisini araştırmaktadırlar. Yazarların geliştirmiş oldukları model ve araştırma sonuçların incelendiğinde psikolojik sahiplenmenin örgütsel bağlılık ve işgörenlerin bilgi paylaşımı'nı olumlu yönde etkilediği görülürken, İşgörenlerin kararlara katılımının da psikolojik sahiplenme üzerinden örgütsel bağlılık ve işgören bilgi paylaşımına olumlu yönde etkilediği görülmektedir (Han vd., 2010: 2224-2229).

Bilgi teknolojilerin psikolojik olarak sahiplenilmesi üzerinden bilgi teknolojilerinin uygulanması ve kabulünü araştıran Barky vd. (2008) bilgi teknolojilerini psikolojik olarak sahiplenmenin, bilgi teknolojilerinin kullanımını ve kabulünü olumlu anlamda etkilediğini bulgulamışlardır. $\mathrm{Bu}$ bağlamda PS'nin değişime direnci kırdığı değerlendirilebilir.

Farklı bir bakış açısı ve özgün bir tasarımla sanal dünya ve bireylerin psikolojik sahiplenme durumunu araştıran Lee ve Chen (2011), tüm dünyada yaklaşık olarak 10 milyon kullanıcısı bulunan ikinci yaşam (Second Life, burada kullanıcılar sanal olarak mal mülk sahibi olmakta çeşitli aktivitelere katılmakta, özetle sanal bir ekonomi yaratılmaktadır.) 


\section{Z.UÇAR}

web sitesinde, kullanıcılarının sanal olarak deneyimlemiş oldukları bu olgulara karşı geliştirmiş oldukları psikolojik sahiplenme duygusuna ilişkin ilişkileri araştırmışlardır. Çalışma sonucunda çeşitli web site özellikleri (okunabilirlik, sertlik, tutarlılık, çeşitlilik, gizem, klasik olma, etkileyici görsel estetikler), kişilerin sanal dünyada harcadıkları zaman, daha fazla aktiviteye katılım ve siteyi ziyaret etme sıklıkları ile psikolojik sahiplenme durumları arasında pozitif yönde ilişkiler bulgulamışlardır. Araştırmacılar bu bulguların e-iş yöneticilerine kendi sınırlı kaynaklarıyla kullanışı bir sanal dünya dizayn etmelerinde öncülük edeceğini belirtmektedirler.

Brown vd., (2005), işgörenlerin sosyal yada fiziksel bir hedef nesneye yönelik geliştirmiş oldukları psikolojik sahiplenmenin dışa vurumu olarak bölgecilik (Territoriality) kavramını ön plana çıkarmaktadırlar. Brown vd., (2005) PS’yi bölgeci davranışların bir öncülü olarak değerlendirmektedir. Dolayısıyla psikolojik anlamda sahiplenme hissinin yüksek düzeyde olduğu işgörenlerde bu davranış biçiminin ortaya çıkmasının daha olası olduğunu belirtmektedir. Çalışanlar, fiziksel alanlar, fikirler, roller, ilişkiler vb. potansiyel hedef nesneleri aşırı bağlı olarak bölgeci davranışlar sergileyebilmektedir. Bölgeciliğe bağlı olarak sergilenen davranışların örgütler açısından olumlu veya olumsuz sonuçları olabilmektedir. Örneğin, bölgecilik, sosyal gruplara aidiyet duyma hissini katkı sağlamasıyla işgücü devir oranında azalma ve performans artışı gibi olumlu örgütsel çıktılar sağlarken; diğer taraftan, işgörenlerin sahiplik iddialarıyla fazla meşgul olmaları, performanslarını olumsuz olarak etkilemekte ve örgütsel amaçlara odaklanmalarını engellemektedir (Brown vd., 2005: 577-578). Hernekadar Brown vd., (2005) tarafindan PS'nin bölgeciliğin öncülü olarak değerlendirilse de Avey vd., (2009) bu iddianın tam aksini belirterek, bölgecilik hissinin önleyici psikolojik sahiplenmenin 
öncülü yada boyutlarından biri olabileceğini değerlendirmektedirler. Aslında bu durum her iki çalışmanın konuya farklı açıdan bakmasından kaynaklanmaktadır. Brown vd.'nin (2005) somut davranışlara odaklandığ görülürken, Avey vd.'nin (2009) ise bölgeciliğin bilişsel unsurları üzerine odaklandıkları anlaşılmaktadır. Nitekim Avey vd. (2009)'e göre bölgecilik hissinin bireyin sahiplik hissettiği hedef nesneyle çok daha fazla meşgul olmaları sonucunu doğurmakta ve iş birliği, bilgi paylaşımı gibi örgüt yararına olabilecek konularda, benlik ve sosyal kimlikle bütünleştirilen hedef nesneyi kaybetme korkularına bağlı olarak önleyici davranışlar göstermelerine neden olmaktadır. Ancak kolektif çalışmanın aksine bireysel çalışmanın önemli olduğu durumlarda, bireyler bölgeci davranışlar sergileyerek doğru olanı yaptıklarına inanabilmekte ve bireysel performans artışı görülebilmektedir (Avey vd., 2009; s. 177). Dolayısıyla her iki araştırmanın da ortak noktası olarak bölgeciliğin hem olumlu hem de olumsuz sonuçlarının olduğu söylenebilir.

\section{SONUÇ}

Psikolojik sahiplenme son zamanlarda dış yazında ivme kazanmış ve örgütsel alana ilişkin karanlıkta kalan noktaları daha iyi açıklaması bakımından önemli bir çalışma haline gelmiştir. Özelliklede işgörenlerin çalışmış oldukları işyerlerine karşı olumlu tutumlar geliştirmeleri, sorumluluk duygusu içerisinde hareket etmeleri, daha iyi motive olmaları, bağlılık hissetmeleri, örgütsel vatandaşlık davranışları sergilemeleri gibi örgütsel açısından çok önemli olan temel konularda olumlu yönde etkilerinin olduğu görülmüştür. Ancak olgunun örgüt alanı içerisinde ne şekilde geliştiği ve çıktıları üzerine yapılan araştırmaların yeterli düzeyde olmadığ 1 bir kısım araştırmacılar tarafından da değerlendirilmektedir. $\mathrm{Bu}$ 


\section{Z.UÇAR}

temel sorunsala bağlı olarak PS olgusunun bütüncül bir yaklaşımla ele alındığı bu çalışma sonraki çalışmalara kuramsal altyapı hazırlaması bakımından önemlidir. Nitekim bu çalışma içerisinde PS olgusunun örgütsel alan içerisinde oluşumu ve örgüt alanı içerisindeki etkileri ayrıntılı bir model üzerinden ele alınarak tartışılmıştır. Alana ilişskin bütüncül bir yaklaşım ortaya konarak psikolojik sahiplenme olgusunun teorileşme çabasına bağlı olarak ne şekilde kavramsallaştığı açı bir biçimde ortaya konmaya çalışılmıştır.

Örgütsel alanda PS'nin oluşumunu sağlayan çeşitli koşulsal faktörlerin olduğu anlaşılmaktadır. PS'nin boyutları olarak ele alınan etkinlik/etkililik, öz kimlik, bir alana sahip olma güdüsü yönetim felsefesine bağlı olarak, örgüt yapı ve özelliklerinden etkilenmektedir. Özellikle de merkezileşmenin ve hiyerarşinin düşük olduğu, kararlara katılım derecesinin yüksek olduğu organik örgüt yapıları içerisinde PS olgusunun daha yüksek düzeylerde ortaya çıktığı anlaşılmıştır. Bu tür yapılar içerisinde bireyler örgütleri ve/veya işleri üzerinde daha fazla kararlara katılım ve kontrole sahip olduklarından hedef nesneyi yakından tanıma imkânı bulmakta ve ona öz yatırım yapmak için daha istekli hale gelmektedirler. PS'nin oluşumunu sağlayan bu koşullar altında birey çalışmış olduğu işyerine karşı olumlu tutumlar geliştirmekte ve içsel motivasyonlarının da etkisiyle çeşitli olumlu davranışlar sergilemektedirler. Nitekim birçok araştırmacı tarafından ortaya konan bu sonuç konunun örgütler açısından ne denli önemli olduğunu da ortaya koymaktadır.

Araştırmalar bütünsel olarak değerlendirildiğinde örgüt alanına ilişkin olarak ele alınacak psikolojik sahiplenme olgusuna ilişkin sağlam bir teorinin oluştuğunu iddia etmek güçtür. Ancak bu araştırmaya özgün 
geliştirilen model üzerindeki ilişkiler seti üzerinden geliştirilecek hipotezlerin sonraki ampirik araştırmalarla sınanıp doğruluğunun yada yanlışlığının ortaya konması ve PS olgusunun teorileşmesine katkı sağlayacağı düşünülmektedir.

\section{KAYNAKÇA}

ASATRYAN, V. S., OH, H. (2008), "Psychological Ownership Theory: An Exploratory Application in The Restaurant Industry", Journal of Hospitality \& Tourism Research, 32: 363-386.

AVEY, J. B., AVOlio, B. J., CROSSley, C. D., LUThANS, F. (2009), "Psychological Ownership: Theoretical Extensions, Measurement and Relation to Work Outcomes", Journal of OrganizationalBehavior, 30(2), 173-191.

AVEY, J. B.,WERNSING, T. S., PALANSKI, M. E. (2012), "Exploring The Process of Ethical Leadership: The Mediating Role of Employee Voice and Psychological Ownership", Journal of Business Ethics, 107(1), 21-34.

BARKI, H.,PARÉ, G., SİCOTTE, C. (2008), "Linking IT Implementation and Acceptance Via The Construct of Psychological Ownership of İnformation Technology", Journal of Information Technology, 23(4), 269-280.

BERNHARD, F., O'DRISCOLL, M. P. (2011), "Psychological Ownership in Small Family-Owned Businesses: Leadership Style and Nonfamily-Employees' Work Attitudes and Behaviors", Group \& Organization Management, 36(3), 345384.

BROWN, G., LAWRENCE, T. B., ROBINSON, S. L. (2005), "Territoriality in Organizations", Academy of Management Review, 30(3), 577-594.

BUCHKO, A. A. (1992), "Effects of Employee Ownership on Employee Attitudes a Test of Three Theoretical Perspectives", Work and Occupations, 19(1), 59-78.

CHI, N. W., HAN, T. S. (2008), 2Exploring The Linkages Between Formal Ownership And Psychologica Lownership for The Organization: The Mediating Role of Organizational Justice", Journal of Occupational and Organizationa lPsychology, 81(4), 691-711. 


\section{Z.UÇAR}

ETZIONI, A. (1991), "The Socio-Economics of Property. In F. W. Rudmin (Ed.), To Have Possessions: A Hand Book on Ownership and Property", Special Issue, Journal of Social Behavior and Personality, 6(6), 465-468.

FLORKOWSKI, G. W. (1987), "The Organizational Impact of Profit Sharing", Academy of management Review, 12(4), 622-636.

GHAFOOR, A., QURESHI, T. M., Khan, M. A., HIJAZI, S. T. (2011), "Transformational Leadership, Employee Engagement and Performance: Mediating Effect of Psychological Ownership", Africanjournal of businessmanagement, 5(17), 7391-7403.

HAN, T. S., CHIANG, H. H., CHANG, A. (2010), "Employee Participation in Decision Making, Psychological Ownership and Knowledge Sharing: Mediating Role of Organizational Commitment in Taiwanese High-Tech Organizations", The International Journal of Human Resource Management, 21 (12), 2218-2233.

KAUR, D.,SAMBASIVAN, M., KUMAR, N. (2013), "Effect of Spiritual İntelligence, Emotional İntelligence, Psychological Ownership and Burnout on Caring Behaviour of Nurses: A Cross-Sectional Study", Journal of clinicalnursing, 22(21-22), 3192-3202.

KUBZANSKY, P. E., DRUSKAT, V. U. (1993), "Psychological Sense of Ownership in Theworkplace: Conceptualization and Measurement", In Annual Meeting of The American Psychological Association, Toronto, Ontario.

LEE, Y., CHEN, A. N. (2011), "Usability Design and Psychological Ownership of A Virtual World", Journal of Management Information Systems, 28(3), 269-308.

LERNER, J. S., TETLOCK, P. E. (1999), Accounting Forthe Effects of Accountability", Psychological Bulletin, 125, 255-275.

LIU, J.,WANG, H., HUI, C., LEE, C. (2012), "Psychological Ownership: How Having Control Matters", Journal of Management Studies, 49(5), 869-895.

MAYHEW, M. G.,ASHKANASY, N. M., BRAMBLE, T., GARDNER, J. (2007), "A Study of The Antecedents and Consequences of Psychological Ownership in Organizational Settings", The Journal of social psychology, 147(5), 477-500.

O'DRISCOLL, M. P., PIERCE, J. L., COGHLAN, A. M. (2006), “The psychology of ownership work environment structure, organizational commitment, and citizenship behaviors", Group \& Organization Management, 31(3), 388-416. 
OLCKERS, C., DUPLESSIS, Y. (2012), "Psychological Ownership: A Managerial Construct for Talent Retention and Organisational Effectiveness", African Journal of Business Management, 6(7), 2585.

PIERCE, J. L., FURO, C. A. (1991), "Employee Ownership: Implications for Management", Organizational Dynamics, 18(3), 32-43.

PIERCE, J. L., RUBENFELD, S. A., Morgan, S. (1991), "Employee Ownership: A Conceptual Model of Process and Effects", Academy of Management Review, 16(1), 121-144.

PIERCE, J. L., JUSSILA, I. (2010), "Collective Psychological Ownership within The Work and Organizational Context: Construct Introduction and Elaboration", Journal of Organizational Behavior, 31(6), 810-834.

PIERCE, J. L.,\&RODGERS, L. (2004), "The Psychology of Ownership and Worker-Owner Productivity", Group \& Organization Management, 29(5), 588613.

PIERCE, J. L., JUSSILA, I., CUMMINGS, A. (2009), "Psychological Ownership within The Job Design Context: Revision of The Job Characteristics Model", Journal of Organizational Behavior, 30(4), 477-496.

PIERCE, J. L.,KOSTOVA, T., DIRKS, K. T. (2001), "Toward a Theory of Psychological Ownership in Organizations", Academy of Management Review, 26(2), 298-310.

PIERCE, J. L.,KOSTOVA, T., DIRKS, K. T. (2003), "The State of Psychological Ownership: Integrating and Extending a Century of Research", Review of General Psychology, 7(1), 84.

PIERCE, J. L.,O'DRISCOLL, M. P., COGHLAN, A. M. (2004), "Work Environment Structure and Psychologica Lownership: The Mediating Effects of Control", The Journal of Social Psychology, 144(5), 507-534.

RYAN, R. M., DECI, E. L. (2006), "Self-Regulation and The Problem of Human Autonomy: Does Psychology Need Choice, Self-Determination, and Will?", Journal of Personality, 74(6), 1557-1586.

SIEGER, P.,ZELLWEGER, T., AQUINO, K. (2013), "Turning Agents into Psychological Principals: Aligning Interests of Non-Owners through Psychological Ownership", Journal of Management Studies, 50(3), 361-388. 


\section{Z.UÇAR}

VAN DYNE, L., PIERCE, J. L. (2004), "Psychological Ownership and Feelings of Possession: Three Field Studies Predicting Employee Attitudes and Organizational Citizenship Behavior", Journal of Organizational Behavior, 25(4), 439-459.

VANDEWALLE, D., VAN DYNE, L., KOSTOVA, T. (1995). "Psychological Ownership: An Empirical Examination of Its Consequences", Group \& Organization Management, 20(2), 210-226.

WAGNER, S. H., PARKER, C. P., CHRISTIANSEN, N. D. (2003), "Employees That Think and Act Like Owners: Effects of Ownership Beliefs and Behaviors on Organizational Effectiveness". Personnel Psychology, 56(4), 847871.

YILDIZ B., YILDIZ H., (2015), "The Effect of Servant Leadership on Psychological Ownership: The Moderator Role of Perceived Organizational Support", Journal Of Global Strategic Management, vol.9, pp.65-77.

ZHU, H.,CHEN, C. C., LI, X., ZHOU, Y. (2013), "From Personal Relationship to Psychological Ownership: The Importance of Manager-Owner Relationship Closeness in Family Businesses", Management andOrganizationReview, 9(2), 295318. 